Ni Nyoman Ari Novarini, Desak Ayu Sriary Bhegawati

\title{
Pengaruh Inovasi Produk dan Orientasi Pasar terhadap Kinerja Pemasaran melalui Minat Beli Customer sebagai Variabel Intervening pada Usaha Pudding Art di Kota Denpasar
}

\author{
Ni Nyoman Ari Novarini-1 \\ Universitas Mahasaraswati Denpasar \\ Desak Ayu Sriary Bhegawati-2 \\ Universitas Mahasaraswati Denpasar \\ *novarini0511@gmail.com
}

\begin{abstract}
Abstrak
Tujuan penelitian ini adalah untuk menganalisis pengaruh strategi inovasi produk dan orientasi pasar terhadap kinerja pemasaran melalui minat beli customer sebagai variabel intervening pada usaha pudding art di kota Denpasar. Penelitian ini menggunakan data 30 kuesioner yang dikumpulkan dari konsumen puding art yang ada dikota Denpasar sebanyak 30 responden sebagai sampelnya. Dalam penelitian ini dikembangkan suatu model teoritis dengan mengajukan lima hipotesis yang akan diuji dengan menggunakan Path Analysis atau Analisis Jalur dengan menggunakan software SMART PLS 3. Responden yang digunakan dalam penelitian ini diambil dari customer puding art dikota denpasar yang berjumlah 30 orang responden. Hasil analisis data menunjukkan bahwa model penelitian mempunyai kesesuaian yang baik dan semua hipotesis penelitian dapat dibuktikan. Kesimpulan yang diambil adalah strategi inovasi produk berpengaruh positif dan signifikan terhadap kinerja pemsaran usaha puding art dikota Denpasar dan selanjutnya orientasi pasar berpengaruh positif dan signifikan terhadap kinerja karyawan usaha puding art dikota Denpasar, inovasi produk berpengaruh positif dan signifikan terhadap minat beli customer usaha pudding art dikota Denpasar, orientasi pasar berpengaruh positif dan signifikan terhadap minat beli customer pada usaha pudding art dikota Denpasar, serta yang terakhir adalah adanya pengaruh strategi inovasi produk dan orientasi pasar terhadap minat beli customer melalui kinerja pemasaran sebagai variabel intervening pada usaha pudding art dikota Denpasar. Penelitian ini memberikan beberapa keterbatasan penelitian serta agenda penelitian mendatang yang bisa dilakukan pada penelitian lanjutan.
\end{abstract}

Kata kunci: inovasi produk, orientasi pasar, minat beli customer, kinerja pemasaran

\section{Pendahuluan}

Pada era revolusi industry 4.0 saat ini sangat dipengaruhi oleh pengaruh digitalisasi. Saat produsen memasarkan produk juga sangat efektif dan efisien menggunakan aplikasi atau social media marketing. Seorang wirausaha harus lebih aktif, lebih inovatif dan kreatif dalam memadukan produknya sehingga menjadi lebih unik dan menarik. Konsumen menjadi lebih puas dan tertarik untuk mengkonsumsi produk tersebut. Dinamika dalam dunia usaha yang semakin menantang, membuat para wirausaha harus dapat menjawab tantangan pasar dan memanfaatkan tantangan tersebut sebagai peluang untuk dapat bertahan dimasa yang akan datang. Puding Art atau Jelly Art berasal dari kata pudding (bahasa Inggris), adalah hidangan penutup yang tidak hanya dihidangkan dingin segar melainkan juga dalam keadaan panas, hangat, dan lebih kaya rasa. Puding cocok sebagai hidangan penutup yang segar untuk iklim tropis Indonesia. Dengan bahan dasar agar-agar yang kaya serat, cita rasanya lebih nikmat 


\section{Ni Nyoman Ari Novarini, Desak Ayu Sriary Bhegawati}

dengan menambahkan bahan susu dan gula. Dari masa ke masa bermunculan aneka kreasi puding, seiring dengan berkembangnya penemuan bahanbahan baru seperti gelatin dan jelly untuk membuat puding.

Kegiatan pendistribusian produk juga mesti lebih gencar kepada konsumen, karena. Pemasar mencoba mempengaruhi konsumen dengan segala cara dari mulai promosi melalui social media marketing , maupun mouth to mouth agar konsumen bersedia membeli produk yang ditawarkannya, bahkan yang semula tidak ingin, menjadi ingin membeli. Pada prinsipnya konsumen yang menolak hari ini belum tentu menolak hari berikutnya, akibatnya timbul persaingan dalam menawarkan produk-produk yang berkualitas dengan harga yang mampu bersaing di pasaran produk yang berkualitas dengan harga bersaing merupakan kunci utama dalam memenangkan persaingan. Konsumen kini memiliki tuntutan nilai yang jauh lebih besar dan beragam karena dihadapkan pada berbagai pilihan berupa barang maupun jasa yang dapat mereka beli.Berdasarkan tingkat kehidupan masyarakat yang semakin meningkat, maka kebutuhan masyarakat terhadap barang juga akan semakin meningkat. Hal ini membawa pengaruh terhadap perilaku mereka dalam memilih barang yang akan dibeli konsumen benar - benar dapat memenuhi kebutuhan dan keinginan mereka.

Pada era revolusi industri 4.0 ini saat era digital semakin gencar dan booming, maka diperlukan marketing produk yang tepat pula. Baik itu melalui social media marketing maupun kualitas produk dan pelayanan yang terbaik. Oleh sebab itu masyarakat akan sangat tergiur oleh service excellent yang ditawarkan produsen maupun kualitas harus diukur melalui sudut pandang konsumen terhadap kualitas produk itu sendiri, sehingga selera konsumen disini sangat berpengaruh. Jadi dalam mengelola kualitas suatu produk harus sesuai dengan kegunaan yang diinginkan oleh konsumen. Dalam hal ini yang penting adalah menjaga konsistensi dari output produk pada tingkat kualitas yang diinginkan dan diharapkan konsumen.Kualitas produk merupakan kemampuan suatu produk untuk melakukan fungsinya. Kemampuan itu meliputidaya tahan produk, kehandalan produk, ketelitian yang dihasilkan, kemudahan dioperasikan dan diperbaiki, serta atribut produk yang berharga pada produk secara keseluruhan. Industri yang berhasil dalam usahanya adalah industri yang mampu menciptakan formulasi strategi yang tepat, karena strategi yang tepat dapat menentukan keberhasilan UKM dan bisa bersaing pada pasar global. Tujuan perencanaan strategis adalah untuk membentuk serta menyempurnakan usaha bisnis dan produk perusahaan sehingga memenuhi target laba dan pertumbuhan

Utamaningsih (2016) menyatakan permasalahan yang dihadapi UMKM sebenarnya adalah rendahnya produktivitas pada penciptaan produk baru akibat kurangnya daya kreativitas dan inovatif sehingga kinerja pemasaran tidak berjalan dengan stabil. Konsep kinerja pemasaran didukung dengan banyak faktor mulai dari kesadaran akan pandangan terhadap pasar, kesadaran melakukan strategi yang inovatif, kemampuan untuk mengambil risiko dan orientasi dari proses pembelajaran (Haryanto et al., 2017).Schifman dan kanuk (2007) menjelaskan bahwa pengaruh eksternal, kesadaran akan kebutuhan pengenalan produk dan evaluasi alternatif adalah hal yang dapat menimbulkan minat beli konsumen. Pengaruh eksternal ini terdiri dari usaha pemasaran dan faktor sosial budaya. pembelian ulang (repeat purchase) menurut Peter dan Olsen (2002)adalah Kegiatan pembelian yang dilakukan lebih dari satu kali atau beberapa kali.Kepuasan yang diperoleh seorang konsumen, dapat mendorong ia melakukan pembelian ulang (repeat purchase), menjadi loyal terhadap produk tersebut ataupun loyal terhadap toko tempat dia membeli barang tersebut sehingga konsumen dapat menceritakan hal-hal yang baik kepada orang lain. Berdasarkan hal tersebut diatas tujuan penelitian ini adalah untuk mengetahui pengaruh inovasi produk dan orientasi pasar terhadap kinerja pemasaran usaha puding art di Kota Denpasar yang dimediasi/intervening oleh minat beli konsumen. 


\section{Landasan Teori dan Pengembangan Hipotesis}

Inovasi produk merupakan suatu proses yang berusaha memberikan solusi terhadap permasalahan yang ada. Permasalahan yang sering terjadi di dalam bisnis adalah produk yang bagus tetapi mahal atau produk yang murah tetapi tidak berkualitas. Inovasi produk seharusnya mampu memberikan nilai tambah dibanding produk sejenis(keunggulan produk) sehingga dapat menjadikan perusahaan memilikikeunggulan dibandingkan pesaingnya. Indikator Inovasi produk menurut Cahyo dan Harjani (2013) dan Atalay, et al (2013) adalah Perusahaan membuat packaging desain produk yang berbeda dari pesaing, Perusaahaan menambahkan varian produk baru, Perusahaan menambahkan fitur varian produk, Perusahaan melakukan kualitas kontrol sebelum produk dipasarkan, Perusahaan memiliki standar kualitas produk, Perusahaan mengembangkan kualitas produk. Menurut Kotler, (2008) Orientasi pasar merupakan implementasi dari konsep pemasaran yang mampu memberikan nilai unggul kepada konsumen. Indikator orientasi pasar menurut Hererro, et al (2017), Ozsahin (2013) dan Putri, dkk (2016) adalah Orientasi pelanggan, orientasi pesaing dan koordinasi antar fungsional.

Menurut Kotler (2008), minat beli konsumen adalah sesuatu yang timbul setelah menerima rangsangan dari produk yang dilihatnya, dari sana timbul ketertarikan untuk mencoba produk tersebut sampai pada akhirnya timbul keinginan untuk membeli agar dapat memilikinya Minat Beli menurut Tjiptono (2007), minat beli dapat diidentifikasi melalui indikatorindikator : 1) Minat transaksional, yaitu kecenderungan seseorang untuk membeli produk, 2) Minat refrensial, yaitu kecenderungan seseorang untuk mereferensikan produk kepada orang lain, 3) Minat preferensial, yaitu minat yang menggambarkan perilaku seseorang yang memiliki prefrensi utama pada produk tersebut. Preferensi ini hanya dapat diganti jika terjadi sesuatu dengan produk prefrensinya, dan 4) Minat eksploratif, minat ini menggambarkan perilaku seseorang yang selalu mencari informasi mengenai produk yang diminatinya dan mencari informasi untuk mendukung sifat-sifat positif dari produk tersebut. Kinerja adalah hasil kerja secara kualitas dan kuantitas yang dicapai oleh seorang pegawai dalam melaksanakan tugasnya sesuai dengan tanggung jawab yang diberikan kepadanya hal ini dikemukakan oleh Mangkunegara (Sutedjo dan Mangkunegara, 2018). Kinerja menurut Sutanto dan Suwondo (2015) sesuai indikator diukur dengan dengan (1) Ketepatan waktu dalam menyelesaikan pekerjaan, yaitu ketelitian dalam menyelesaikan pekerjaan, perhatian pada kualitas dalam penyelesaian pekerjaan, kemampuan memenuhi target perusahaan dan kemampuan menyelesaikan pekerjaan dengan tepat waktu. (2) Tingkat inisiatif dalam bekerja, antara lain kemampuan mengantisipasi masalah yang mungkin terjadi dan kemampuan untuk membuat solusi alternatif bagi masalah tersebut.(3) Kecekatan mental, kecekatan mental diukur melalui kemampuan karyawan dalam memahami arahan yang diberikan oleh pemimpin dan kemampuan karyawan untuk bekerjasama dengan rekan kerja lain.(4) Kedisiplinan waktu dan absensi, merupakan tingkat ketepatan waktu dan tingkat kehadiran karyawan di tempat kerja. Berdasarkan Keterkaitan konsep tersebut dapat digambarkan hubungan inovasi produk, orientasi pasar, minat beli customer, dan kinerja karyawan sebagai berikut. 


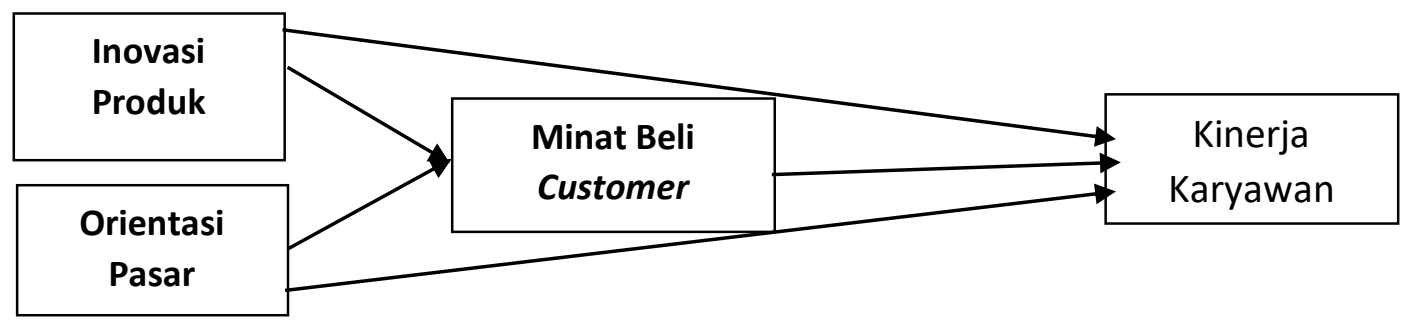

Gambar 1. Hubungan inovasi produk, orientasi pasar, minat beli customer, dan kinerja karyawan

Sumber : Hasil Pemikiran Peneliti (2020)

Hipotesis yang dapat diuraikan berdasarkan hubungan konsep tersebut adalah peran inovasi produk memediasi orientasi pasar terhadap kinerja pemasaran (studi pada usaha mikro, kecil dan menengah pie susu di kota Denpasar) Menurut Nusanti Putri (2018). Hasil penelitian lain Adanya pengaruh antara inovasi produk dan harga terhadap minat beli Toyota yaris auto 2000 di Sidoarjo dikatakan oleh Aprilia Hidayatullah (2016). Hal ini mampu merumuskan hipotesis, yaitu

H1: Inovasi Produk berpengaruh positif dan signifikan terhadap Minat Beli Customer Puding Art Di Kota Denpasar.

Adanya pengaruh antara citra merek, kualitas produk dan harga terhadap minat beli konsumen ORIFLAME (Studi Kasus pada Mahasiswi Fakultas Ekonomika dan Bisnis Universitas Diponegoro Semarang) hal ini dikatakan oleh Ikanita Novirina (2012), maka mampu merumuskan hipotesisnya yaitu

H2: Orientasi Pasar berpengaruh positif dan signifikan terhadap Minat Beli Customer Puding Art Di Kota Denpasar.

Inovasi produk berpengaruh positif dan signifikan terhadap kinerja pemasaran pada penelitian yang dilakukan di United Kingdom (Parkman et al., 2012). Penelitian yang sejalan juga dikemukakan oleh Chaston dan Scoot (2012), kemudian Inovasi Produk berpengaruh positif dan signifikan terhadap Keunggulan Bersaing pada Industri Kerajinan Batok Kelapa di Kabupaten Karangasem, (Bhegawati \& Yuliastuti, 2019).Perbedaan lain pada penelitian yang dilakukan oleh Quantsnanda dan Bambang (2015) menyatakan inovasi tidak dapat berpengaruh secara signifikan terhadap kinerja dari pemasaran. maka mampu merumuskan hipotesisnya yaitu

H3: Inovasi Produk berpengaruh positif dan signifikan terhadap Kinerja Pemasaran Usaha Puding Art Di Kota Denpasar.

Adanya pengaruh orientasi pasar positif dan signifikan terhadap kinerja pemasaran air minum dalam kemasan (amdk) pada PT. Umega Sembilan Berlian Gunung Medan Dharmasaraya yang dikemukakan oleh Aldo \& Mayliza ( 2019).

H4: Orientasi Pasar berpengaruh secara positif dan signifikan terhadap kinerja pemasaran Usaha Puding Art Di Kota Denpasar. 


\section{Ni Nyoman Ari Novarini, Desak Ayu Sriary Bhegawati}

Begitu juga orientasi pasar, orientasi pembelajaran, dan inovasi produk sebagai variabel intervening mempunyai pengaruh signifikan terhadap kinerja pemasaran berdasarkan dari penelitian analisis pengaruh orientasi pasar, orientasi pembelajaran terhadap inovasi produk, dan kinerja pemasaran (studi pada sentra industri kecil rumah tangga kerajinan anyaman pandan di desa grenggeng kecamatan karanganyar kabupaten kebumen) yang dikemukakan oleh Wiwoho Gunarso (2013) maka dapat disimpulkan hipotesis berikut ini

H5: Inovasi Produk dan Orientasi Pasar berpengaruh secara signifikan terhadap Kinerja Pemasaran melalui Minat Beli Konsumen Usaha Puding Art Di Kota Denpasar.

\section{Metode Penelitian}

Penelitian ini dilakukan di wilayah Kota Denpasar dengan tahun penelitian yang dilakukan pada tahun 2020. Obyek penelitian ini adalah khususnya mengenai Inovasi Produk, Orientasi Pasar terhadap Minat Beli Customer Pudding Art Di Kota Denpasar. Variabel dalam penelitian ini terdiri dari variabel independen yaitu inovasi produk $\left(\mathrm{X}_{1}\right)$, dan Orientasi Pasar $\left(\mathrm{X}_{2}\right)$. Selain itu terdapat variabel intervening yaitu minat beli customer $(\mathrm{M})$, dan Variabel dependen yaitu kinerja karyawan (Y).Adapun definisi operasional variabel tersebut adalah sebagai berikut.

Strategi inovasi produk yang dikemukakan oleh Cahyo dan Harjani (2013) dan juga Atalay, et.al (2013) yaitu :1) Perusahaan membuat packaging desain produk yang berbeda dari pesaing, 2) Perusaahaan menambahkan varian produk baru, 3) Perusahaan menambahkan fitur varian produk, 4) Perusahaan melakukan kualitas kontrol sebelum produk dipasarkan, 5) Perusahaan memiliki standar kualitas produk, dan 6) Perusahaan mengembangkan kualitas produk.

Orientasi Pasar yang dikemukakan oleh Hererro, et al (2017), Ozsahin (2013) dan Putri, dkk (2016) adalah Orientasi pelanggan, orientasi pesaing dan koordinasi antar fungsional. minat beli konsumen adalah menurut Tjiptono (2007), minat beli dapat diidentifikasi melalui indikator-indikator yaitu : 1) Minat transaksional, yaitu kecenderungan seseorang untuk membeli produk, 2) Minat refrensial, yaitu kecenderungan seseorang untuk mereferensikan produk kepada orang lain, 3) Minat preferensial, yaitu minat yang menggambarkan perilaku seseorang yang memiliki prefrensi utama pada produk tersebut. Preferensi ini hanya dapat diganti jika terjadi sesuatu dengan produk prefrensinya, 4) Minat eksploratif, minat ini menggambarkan perilaku seseorang yang selalu mencari informasi mengenai produk yang diminatinya dan mencari informasi untuk mendukung sifat-sifat positif dari produk tersebut. Kinerja pemasaran menurut Nasution dan Zaini, et al (2014) yang mengatakan bahwa indikator dari kinerja pemasaran adalah Pertumbuhan penjualan usaha meningkat dalam 3 tahun terkahir, volume usaha penjualan meningkat dalam 3 tahun terakhir, pengembalian modal dapat dipenuhi, Pertumbuhan pelanggan usaha meningkat dalam 3 tahun Terakhir.

Jenis data dalam penelitian ini adalah data Kualitatif yaitu berupa data yang tidak dapat dihitung atau data yang tidak berupa angka-angka, seperti sejarah usaha dan data Kuantitatif berupa angka-angka yang dapat dihitung secara matematis maupun yang disajikan dalam bentuk tabel, seperti jumlah responden, umur responden, jenjang pendidikan responden, dll. Sumber data yang digunakan adalah data primer dan data sekunder.

Populasi dalam dalam penelitian ini adalah konsumen pudding art dikota denpasar, Metode penentuan sampel pada penelitian ini menggunakan metode sensus dengan sampel dalam penelitian ini adalah 30 orang. Teknik pengambilan sampel menggunakan sampel jenuh (Sugiyono, 2011) yang menyatakan jika sampel kurang 100 orang maka bisa dipakai seluruh 


\section{Ni Nyoman Ari Novarini, Desak Ayu Sriary Bhegawati}

populasi sebagai sampel. Pengumpulan data dilakukan yaitu : 1) Metode Observasi dengan mengadakan pengamatan langsung ke objek penelitian, 2) Metode Kuisioner dengan menyediakan angket yang berisikan pertanyaan-pernyataan untuk seterusnya diisi oleh para responden sesuai pendapatnya masing-masing yang erat kaitannya dengan semangat dan disiplin kerja. Dalam kuesioner digunakan system skala likert untuk menilai alternatif jawaban sesuai dengan pernyataan, dan 3) Metode wawancara dengan melakukan tanya jawab langsung kepada para pegawai yang berkaitan dengan penelitian.

Teknik analisis data yang digunakan dalam penelitian ini menggunakan skala likert.Skala Likert digunakan untuk mengukur sikap, pendapat, dan presepsi seseorang atau sekelompok orang tentang fenomena sosial (Sugiyono, 2011) Dengan skala likert, maka variabel yang akan diukur dijabarkan menjadi indikator variabel.

\section{Pembahasan}

Berdasarkan karakteristik responden menurut jenis kelamin, maka dari 35 responden yang dikumpulkan didapat sebanyak 16 orang atau 53,3\% yang berjenis kelamin laki-laki, sedangkan sebanyak 14 orang atau 46,7\% sisanya berjenis kelamin perempuan. Berdasarkan umur responden $<21$ tahun sebanyak 9 orang atau $30 \%$ kemudian responden yang berumur antara 31-40 tahun sebanyak 21 orang atau 70\%. Berdasarkan pendidikan, maka dari 30 responden yang diteliti terdapat 17 orang atau 56.7\% yang berpendidikan SMU, sebanyak 10 orang atau $33.3 \%$ berpendidikan Diploma, sebanyak 3 orang atau $10 \%$ berpendidikan S1.

Hasil dari Analisis Jalur dengan menggunakan pengolahan data SMART PLS 3 maka dapat dikatakan bahwa inovasi produk berpengaruh positif dan tidak signifikan terhadap kinerja karyawan. Hal ini dibuktikan dengan nilai original sampel 0.267 yang berpengaruh positif dan nilai signifikansi 0.265 yang lebih besar dari 0,05 . maka disimpulkan bahwa Inovasi produk berpengaruh positif dan tidak signifikan terhadap kinerja pemasaran

Inovasi produk berpengaruh positif dan signifikan terhadap minat beli customer. Hal ini dibuktikan dengan nilai original sampel 0.612 yang berpengaruh positif dan nilai signifikansi 0.000 yang lebih kecil dari 0,05 maka disimpulkan bahwa Inovasi produk berpengaruh positif dan signifikan terhadap minat beli customer.

Minat beli customer berpengaruh positif dan signifikan terhadap kinerja pemasaran. Hal ini dibuktikan dengan nilai original sampel 0,577 yang berpengaruh positif dan nilai signifikansi 0.002 yang lebih kecil dari 0,05 maka disimpulkan bahwa minat beli customer berpengaruh positif dan signifikan terhadap kinerja karyawan.

Orientasi pasar berpengaruh positif dan signifikan terhadap kinerja pemasaran. Hal ini dibuktikan dengan nilai original sampel 0,114 yang berpengaruh positif dan nilai signifikansi 0.501 yang lebih besar dari 0,05 maka disimpulkan bahwa orientasi pasar berpengaruh positif dan tidak signifikan terhadap kinerja karyawan.

Orientasi pasar berpengaruh positif dan signifikan terhadap minat beli customer. Hal ini dibuktikan dengan nilai original sampel 0,328 yang berpengaruh positif dan nilai signifikansi 0.020 yang lebih kecil dari 0,05 maka disimpulkan bahwa orientasi pasar berpengaruh positif dan signifikan terhadap minat beli customer.

Penelitian ini bersesuaian dengan penelitian menurut Effendy, A. (2013) yang mengemukakan bahwa adanya pengaruh customer value proposition terhadap minat beli konsumen pada produk consumer pack premium baru bogasari. Selain itu penelitian ini juga bersesuaian dengan penelitian Widarti, D. T. (2011) yang membahas pengaruh orientasi pasar dan inovasi produk terhadap kinerja pemasaran (Studi Kasus Pada Sentra Industri Pembuatan Tahu Kecamatan Sragen Kabupaten Sragen" (Doctoral dissertation, Universitas Negeri Semarang). Menurut Aditi, B. (2017) yang menyatakan bahwa Analisis Pengaruh Inovasi 


\section{Ni Nyoman Ari Novarini, Desak Ayu Sriary Bhegawati}

Produk, Harga, Dan Sertifikasi Halal terhadap minat beli ulang melalui kepuasan konsumen UMKM Di Kota Medan.

\section{Kesimpulan}

Berdasarkan perumusan masalah dan pembahasan pada bab sebelumnya maka dapat diambil kesimpulan yaitu inovasi produk berpengaruh positif dan tidak signifikan terhadap kinerja pemasaran, hal ini berarti jika inovasi produk meningkat maka kinerja pemasaran menurun. Inovasi produk berpengaruh positif dan signifikan terhadap minat beli customer, hal ini berarti bahwa jika inovasi produk meningkat maka minat beli customer. Minat beli customer berpengaruh positif dan signifikan terhadap kinerja pemasaran, hal ini berarti bahwa jika minat beli customer meningkat maka kinerja pemasaran akan meningkat. Orientasi pasar berpengaruh positif dan signifikan terhadap kinerja pemasaran, hal ini berarti bahwa jika orientasi pasar semakin baik maka kinerja pemasaran akan meningkat. Orientasi pasar berpengaruh positif dan signifikan terhadap minat beli customer, hal ini berarti bahwa jika orientasi pasar semakin baik maka minat beli customer akan meningkat. Pihak perusahaan dalam memimpin usaha harus lebih memperhatikan pengaruh inovasi produk yaitu pada penambahan varian produk baru disesuaikan dengan permintaan pasar. Hal ini didapatkan dari hasil tanggapan responden skor rata- rata terendah. Selanjutnya dari minat beli didapatkan hasil skor rata- rata terendah yaitu yaitu kecenderungan seseorang untuk mereferensikan produk kepada orang lain. Dalam hal kinerja pemasaran yang perlu diperhatikan oleh pimpinan usaha adalah bagaimana pertumbuhan pelanggan usaha meningkat dalam 3 tahun terakhir.

\section{Daftar Pustaka}

Aditi, B. (2017) "Analisis Pengaruh Inovasi Produk, Harga, Dan Sertifikasi Halal Terhadap Minat Beli Ulang Melaluikepuasan Konsumen Umkm Di Kota Medan”.Proceedings Roundtable for Indonesian Entrepreseurship Educators Ke-5 / Isfenti Sadalia [et.al] Medan.Hal 40.

Aldo, M., \& Mayliza, R. (2019) "Pengaruh Orientasi Pasar Dan Kreatifitas Terhadap Kinerja Pemasaran Air Minum Dalam Kemasan (Amdk) Pada PT. Umega Sembilan Berlian Gunung Medan Dharmasaraya".Jurnal OSF Vol 1 No.1. Hal 1-7.

Astiti, N. P. Y., \& Novarini, N. N. A. (2019, February). Pengaruh inovasi dan kreativitas terhadap entrepreneurial marketing dalam upaya meningkatkan kinerja pemasaran. In Forum Manajemen STIMI Handayani Denpasar (Vol. 17, No. 1, pp. 73-81).

Atalaya, M., Anafarta, N., and Sarvanc, F. (2013) "The Relationship Between Innovation and Firm Performance: an Empirical Evidence From Turkish Automotive Supplier Industry".Procedia-Social and Behavioral Sciences, 75, 226-235.

Bhegawati, D. A. S., \& Yuliastuti, I. A. N. (2019) "Effect Of Product Innovation And Entrepreneurial Orientation On Competitive Advantage In The Coconut Shell Craft Industry In Karangasem Regency". Jurnal Ilmiah Manajemen dan Bisnis, 4(1), 71-89.

Cahyo, R. J., dan Harjani, D. (2013) "Analisis InovasiProduk pada Sektor Usaha Formal dan Informal di Jawa Timur".AGORA, 1 (3).

Chaston, I., dan Scott, G. J. (2012) "Enterpreneurshipand Open Innovation in an Emerging Economy".Journal of Management Decision, 50 (7),1161-1177.

Effendy, A. (2013) "Pengaruh Customer Value Proposition Terhadap Minat Beli Konsumen Pada Produk Consumer Pack Premium Baru Bogasari”. Jurnal Strategi Pemasaran, $1(2), 1-8$. 
Haryanto, A. T., Tulus, H., dan Hunik, S. R. S. (2017) "Market Orientation, Learning Orientation andSmall Medium Enterprises Performance:The Mediating Role of Innovation".International Review of Management and Marketing, 7 (1),484-491.

Hidayatullah, Aprilia. (2016) "Pengaruh antara inovasi produk dan harga terhadap minat beli Toyota yaris auto 2000 di Sidoarjo". Skripsi.

Herrero, A., H. San, M., dan J. Collado. (2017) "Market Orientation and SNS Adoption forMarketing Purposes in Hospitality Microenterprises".Journal of Hospitality and Tourism Management, 34, 30-40.

Kotler, Philip, et all. (2008) "Principles of Marketing. Financial Times Prentice Hall. Lukas, Bryan A., and O. C. Ferrell. 2000". The Effect of Market Orientation on Product Innovation. Vol. 28, No. 2, pages 239-247.

Nasution, A. A. (2014) “Analisis Kinerja PemasaranPT. Alfa Scorpii Medan”.Jurnal Riset Akuntansi dan Bisnis, 14 (1), 1-14.

Novirina, ekanita. (2015) "Analisis Pengaruh Citra Merek, Kualitas Produk Dan Harga Terhadap Minat beli Konsumen Oriflame (Studi Kasus Pada Mahasiswi Fakultas Ekonomika dan Bisnis Universitas Diponegoro Semarang)". Semarang : Badan Penerbit Universitas Diponegoro.

Ozsahin, M., Cemal, Z., A. Zafer, A., Melike, K. S. (2013) "The Effects of Leadership and Market Orientation on Organizational Commitment".Procedia-Social and Behavioral Sciences,99, 363 - 372.

Parkman, I. D., Holloway, S. S., and Sebastio,Helder. (2012) "Creative Industries: AligningEntrepreneurial Orientation and Innovation Capacity".Journal of Research in Marketingand Entrepreneurship, 14 (1), 95-114.

Putri, P. I. P. P., Yasa, N. N. K., \& Rahyuda, I. K. (2016) "The Role of Innovation in Mediating Market Orientation to Company Performance". JDM (Jurnal Dinamika Manajemen), 7(2), 105-116.

Putri, N. K. N., \& Yasa, N. N. K. (2018) "Peran Inovasi Produk Memediasi Orientasi Pasar terhadap Kinerja Pemasaran (Studi pada Usaha Mikro, Kecil dan Menengah Pie Susu di Kota Denpasar)". Matrik: Jurnal Manajemen, Strategi Bisnis Dan Kewirausahaan, 111-120.

Peter, J. Paul dan Jerry C.Olson. (2002) "Consumer Behavior and Marketing Strategy".Sixth Edition. McGraw-Hill Irwin.

Quantananda, E., Bambang, H. (2015) "Pengaruh Orientasi Kewirausahaan pada Perusahaan Makanan dan Minuman di Surabaya".Jurnal Agro, 3 (1), 706-715.

Schiffman dan Kanuk .(2007) "Perilaku Konsumen”. Edisi Kedua : Jakarta. PT. Indeks Gramedia.

Sugiyono (2011) "Metode Penelitian Kuantitatif Kualitatif dan Resouces and Development". Alfabeta: Jakarta.

Sutanto, E. M., \& Suwondo, D. I. (2015) "Hubungan lingkungan kerja, disiplin kerja, dan kinerja karyawan”. Jurnal manajemen dan kewirausahaan, 17(2), 135-144.

Sutedjo, A. S., \& Mangkunegara, A. P. (2018) "Pengaruh Kompetensi dan Motivasi Kerja terhadap Kinerja Karyawan di PT. Inti Kebun Sejahtera". BISMA (Bisnis dan Manajemen), 5(2), 120-129.

Tjiptono,F. (2007) “Strategi Pemasaran”. Edisi Kedua. Yogyakarta : Andi Ofset.

Utamaningsih, A. (2016) "Pengaruh Orientasi Pasar,Inovasi, dan Kreativitas Strategi Pemasaranterhadap Kinerja Pemasaran pada UKM Kerajinan Rotan di Desa Teluk Wetan, Welahan,Jepara “.Jurnal Media Ekonomi dan Manajemen, 31 (2), 2503-4460.

Wiwoho, G. (2013) "Analisis Pengaruh Orientasi Pasar, Orientasi Pembelajaran Terhadap Inovasi Produk, Dan Kinerja Pemasaran (Studi pada Sentra Industri Kecil Rumah 
INOBIS: Jurnal Inovasi Bisnis dan Manajemen Indonesia

Volume 03, Nomor 03, Juni 2020

Ni Nyoman Ari Novarini, Desak Ayu Sriary Bhegawati

Tangga Kerajinan Anyaman Pandan di Desa Grenggeng Kecamatan Karanganyar Kabupaten Kebumen)". Fokus Bisnis: Media Pengkajian Manajemen dan Akuntansi, 12(2).

Zaini, Achmad., Hadiwidjojo, D., Rohman, F., and Maskie, G. (2014) "Effect Of Competitive Advantage As A Mediator Varible Of Entrepreneurship Orientation To Marketing Performance". IOSR Journal of Business and Management (IOSR-JBM), 16 (5): 05-10.

Widarti, D. T. (2011). "Pengaruh Orientasi Pasar dan Inovasi Produk Terhadap Kinerja Pemasaran (Studi Kasus Pada Sentra Industri Pembuatan Tahu Kecamatan Sragen Kabupaten Sragen" (Doctoral dissertation, Universitas Negeri Semarang). 